\title{
Theoretical and Practical Experiences in the Use and Appreciation of the Audiovisual Aids by Professionals in Education
}

\author{
Abel Alfonso Castro" ${ }^{1, *}$, Yuri Belén Ramírez², Carmen Rosa Seijas Bagué3, \\ Ana María Reyes Suárez ${ }^{4}$, Edward Peter Kardas ${ }^{5}$ \\ ${ }^{1}$ Social Science Department, Faculty of Social and Humanistic Sciences, University of Artemisa, Artemisa, Cuba \\ ${ }^{2}$ Marxism Leninism and History Department, Faculty of Social and Humanistic Sciences, University of Artemisa, Artemisa, Cuba \\ ${ }^{3}$ First Vice-Rectory, Adviser in the University of Pedagogical Science "Enrique José Varona", Havana City, Cuba \\ ${ }^{4}$ Foreign Language Department, Faculty of Social and Humanistic Sciences, University of Artemisa, Artemisa, Cuba \\ ${ }^{5}$ Psychology, Southern Arkansas University, Magnolia, Estados Unidos
}

Email address:

abelac@uart.edu.cu (A. A. Castro), yuribelen8104@gmail.com (Y. B. Ramírez), carmenrsb@ucpejv.edu.cu (C. R. S. Bagué), anitavitoalbe@gmail.com (A. M. R.Suárez), epkardas@saumag.edu (E. P. Kardas)

${ }^{*}$ Corresponding author

\section{To cite this article:}

Abel Alfonso Castro, Yuri Belén Ramírez, Carmen Rosa Seijas Bagué, Ana María Reyes Suárez, Edward Peter Kardas. Theoretical and Practical Experiences in the Use and Appreciation of the Audiovisual Aids by Professionals in Education. International Journal of Information and Communication Sciences. Vol. 6, No. 2, 2021, pp. 22-29. doi: 10.11648/j.ijics.20210602.11

Received: February 6, 2021; Accepted: March 26, 2021; Published: April 20, 2021

\begin{abstract}
The gradual incorporation of information and communication technologies influences all sectors of society, and education is not immune to this phenomenon, which has led to the use of various technological resources, including audiovisual aids. Their adoption poses constant challenges, since it requires knowledge and mastery of skills, so all actors will have to become literate in this regard at some point. The research starts from the systematization of the processes of integration and educational use of Information and Communication Technologies. In that sense, the authors of the following work intend to spread some experiences about the use and appreciation of the audiovisual aids, through theoretical approaches and inquiries made at different levels, educational and work contexts, a methodological procedure is also proposed that guides how to appreciate audiovisual aids, the result of research carried out with students and teachers. For its development, there were used the following methods: historical-logical, analysis and syntheses, explanatory- illustrative and observation, those that were carried out from perceptual processes, like analysis, synthesis, logic, and through abstraction, by allowing an exhaustive study on the theme and promoting the knowledge and development of the ability to appreciate audiovisual aids with their respective operations and actions, elements that are represented through the theoretical and practical experiences disseminated in the body of the work.
\end{abstract}

Keywords: Audiovisual Education, Audiovisual Aids, Ability

\section{Introduction}

TICs are perceived today as an essential component in the education of the XXI century. Its presence makes its use urgent and therefore, it requires a reflection in search of its educational potentialities, its adequate use, adaptation to various scenarios and appreciative possibilities, among other aspects.

As investigative antecedents were consulted different international and national sources that have tried to systematize the processes of integration and school use of the Technologies of the Information and Communication. [1-7]

The Technologies of the Information and Communication (TIC, from this moment on) comprise a very varied set of aids, resources, tools, supports, channels and equipment, that in the last years have been incorporated into educational work. $[8,3,9,10]$

Its incidence is one of the most worrying aspects for educators, due to its capacity to provide support in teaching 
and learning, in a wide range of forms. [11, 12]

It is shared the idea when it is explained: "The assimilation of TICs in the contemporary university should be considered by teachers from two points of view: as a teaching aid that contributes to the perfection of the content in the didactic system of the subjects and as a necessity caused by the transformation of the professional practice." [1].

Regarding TICs as teaching aids, they make possible to perfect the pedagogical practice for exercising a determined influence on the student, for them to, independently of the place they are, the technological conditions, the existent materials and the teacher's physical presence or not, can appropriate the contents by means of the use of aids. [13]

From the previous analysis, it is recognized the idea that TICs consider the audiovisual aids as teaching resources in the educative context and it is understood that the teacher has favorable attitudes towards themselves as preparation for incorporating them into the professional practice, which guarantees its introduction, use and gradual integration.

In this respect, this work addresses some experiences in relation with the use and appreciation of the audiovisual aids, areas poorly explored from the Pedagogical and Social Sciences. That is why, it is necessary to carry out the current research, which promotes the apprehension of knowledge and skills with the spreading of theoretical and practical experiences related to the appreciation of audiovisual aids. It also provides an understanding of the teacher's oral presentations, for the introduction and transmission of information.

Therefore, it is essential to reanalyze: How do the teachers use the audiovisual aids during the teaching learning process? What advantages does the appreciation of the audiovisual aids offer to both, teachers and students in the current circumstances?

Audiovisual aids have a growing penetration power; they are becoming accessible to everyone, whether at homes, on the street and in schools. [9]. This reality implies a challenge for the education system in general and for university teachers as well.

Nowadays, most of the educations, from the initial one to university and postgraduate, use several audiovisual aids like digital texts, pictures, sounds, animated PPT, videos, documentaries, films and multimedia, among others, however, what use it is given to these aids during the teaching learning process?

\section{Main Body}

\subsection{The Audiovisual Aids, Its Classification, Function and Use in the Educative Context}

From the theoretical point of view the scientific community frequently uses a great diversity of terms to name the audiovisual aids: teaching aids [14]; teaching learning audiovisual aids [10]; audiovisual [11, 15]; audiovisual language [16]); didactic audiovisual aids [17]; audiovisual materials [18]; audiovisual resources [19], among others. For the current research, it will be used the term "audiovisual aids" because of the research needs.

Taking into account the authors' experience, it is assumed as audiovisual aids (AVA from this moment on): "They are what fully integrate and interrelate the audible and visual to produce a new reality or language" [20]. This definition is suitable to the research because it allows the study and systematization of the different audiovisual aids, without exceptions. The visual and sound components are explored to conform a new language, in this case, the audiovisual language. In addition, the instrumental and technological are induced by enabling the integration of the components.

The AVA are classified in:

Sound and projection aids, among them the audiovisuals: films, didactic documentaries and videotapes, as well as visuals: slides, photos and audible: recordings.

Aids for the transmission and appropriation of the information: films, videos, educative software, recordings, textbooks and workbooks, encyclopedias and others bibliographic sources, natural and/or preserved objects, plane and three-dimensional aids. [21]

They are educational to the extent they influence on what people learn and on the way they learn; it means their knowledge and about their relation with the knowledge, about the process where reason and emotion, information and representation are mixed. [9]

In this respect, the possibility of educating by means of the AVA depends on its selection, evaluation and integration by the teacher into the pedagogical context, and at the same time, accepted by the student as a means to support the acquisition of learning, that is why its role as a teaching aid.

The AVA as teaching aids "...constitute the process material support and they are used at different levels to satisfy the curriculums and post-graduated programs demands...". [22]

Aspects in which there is a coincidence, since they are used at different educational levels due to their versatility of functions, what makes them into an effective means for supporting the teaching and transmit information.

Their most frequent uses are associated to the functions they perform in the classroom, including:

The knowledge transmission: its utility is because of the representation of information that is exposed to the students without a possibility to interact with the content, what requires the teacher to search and select the ones that best suit the topic to be presented. Fragments also could be selected to adapt them to the necessities and characteristics of the students.

The capacity of capture the students' attention or motivation: the interest or motivation that causes these aids on the students should be focused on learning, taking into account the mentioned educative goals. [23]

Along with the functions mentioned before, the ones provided by the researchers stand out:

To innovate: the AVA constitutes a novelty at first, but through its use, it begins to play its role as a didactic tool. 
To introduce: they can be used for the introduction of a theme, from a general viewpoint, and then, to stimulate the reviewing of specific topics.

To remember: It refers to previous contents, to the new material that is presented.

To structure reality: by means of audiovisual resources, representations of the reality can be made in a symbolic way.

To favor the relation between students and teachers: an atmosphere is created in the classroom where the students show more predisposition for learning.

To form: the acquisition of knowledge, abilities and skills is promoted.

To contrast ideas: it promotes the capacity of analysis; it contrasts conceptions difficult to focus. [24]

Although in the scientific literature, there are other functions associated to the use of these powerful media at the service of the education, there are just illustrated those that, in our opinion, are vital on the development of a developmental teaching-learning process.

From the psychological view, the AVA make possible to assimilate a greater amount of information by simultaneously perceiving it through two senses: sight, an $83 \%$ and hearing, an $11 \%$. [14]

Some advantages are also attributed, among them are:

They provide a concrete base for conceptual thinking so they reduce verbalism.

They easily arouse the audience interest.

They provide the necessary elements for progressive learning, in addition to fixing it with a greater durability.

They stimulate the receptor on his personal performance, closing him to an unknown experience.

They develop the continuity of thought, particularly the filmic materials. [25]

The TICs in general, as the AVA in particular, acquire a vital importance in the educational labor by enriching the teaching learning process, however, at present times, a principle that is fundamental for the authors, is frequently omitted: the principle of audiovisual education. Where media are symbolic systems that need to be read in an active way and that are neither a questionable reflex of the external reality, nor explained by themselves.

Therefore, in current contexts, the audiovisual education allows to promote learning related to the determination of the aids, its characteristics, languages, codes and values, in a way that it can be distinguished from reality and from the phenomena, facts, objects and media representation. This is built, among other ways, through the appreciation of audiovisual aids, which enable comprehension, understanding and communication.

\subsection{The Appreciation of Audiovisual Aids, Its Importance}

The renewal trend opens new challenges for teachers in terms of audiovisual aids appreciation, because they are given a high significance for analysis, reflection, interpretation, valuation, and criticism of objects, processes or phenomena. Also for transforming the pedagogical practice, enriching culture and the socio-educational and psychosocial contextual reality.

In the consulted literature, there are significant contributions of the Cuban scientific community to the appreciative process in a general sense, which are approached from different perspectives.

Starts from the classics, who conceive it by means of the conciliation of the form and contents expressed [26]; through logical operations, ordered by hierarchy for developing the art observation skill. [27] Others see the appreciation of art through the context in which the work is created. [28]

It is associated with the appreciation of the visual arts and it is suggested to sensitize the students that are studying History of Art, with the main Cuban and universal art expressions. [29]

In the tabloid of the course "Introduction to the History of Plastic Art", University for All, it is expressed: "To appreciate is to love with discernment, with criteria; to know reasons that justify the extraordinary sensation of pleasure in front of a determine stimulus. The artistic image is presented like a great challenge to our comprehension capacity. To appreciate the art is to savor the search and enjoy the discovery of something that challenges us from the bottom of the image. [30]

Others researchers confirm it as an ability, which emphasizes the logical operations involved in the appreciation. [31-34]

In a general respect, several positions are defended, from an aesthetic sense of taste and appreciation, through their experiences, thoughts, ideas, feelings, by means of selfdiscovering with the surrounding world. By means of the observation in a first place and with a well delimited purpose; from the comprehension capacity of discerning the extraordinary sensation of pleasure in front of a determined stimulus.

For the research, it will be assumed like an ability because "(...) they constitute the techniques of human activities, they are thought psychological structures that allow assimilating, using and exposing knowledge; they are formed and developed through the exercise of mental actions that are carried out in the cognitive activity, where that knowledge is assimilated and used". [35]

In correspondence with the treated aspects, a bibliographic exploration was made for searching referents that allows to define the audiovisual aids appreciation as an ability, where it is corroborated the absence of researches about this topic, reason why an operational definition was built that would adequate to the research. "The ability to make valuation judgments through the observation, analysis, awareness and interpretation of the reality or language" [36].

Definition that allows highlighting some operations and actions that, in our opinion, could be considered basic when it comes to appreciating audiovisual aids, they are the observation, the analysis, the sensibility, interpretation and valuation.

They are represented in the following chart. 
Table 1. Operations and actions for the appreciation skill. [37]

\begin{tabular}{|c|c|}
\hline \multicolumn{2}{|l|}{ Ability: Appreciate } \\
\hline Operations to be developed & Actions \\
\hline \multirow{3}{*}{$\begin{array}{l}\text { Observation: The planned, motivated, and systematized } \\
\text { perceptions carry out for having knowledge about the } \\
\text { objects, phenomena and processes that surround us. }\end{array}$} & To determine the contexts expressed in the audiovisual aids \\
\hline & To determine the traits expressed in the audiovisual aids \\
\hline & To characterized the contexts expressed in the audiovisual aids \\
\hline \multicolumn{2}{|l|}{ Analysis: consists in an object, phenomenon or process } \\
\hline the essential, the regularities. It coincides with a thought & To determine the criteria of the context decomposition to be analyzed in the audiovisual aid \\
\hline operation, always from the whole to the parts and it is & To delimit the parts of the context to be analyzed in the audiovisual aid \\
\hline $\begin{array}{l}\text { complemented by the synthesis of these elements again, that } \\
\text { is, their reunification in the mental plane. }\end{array}$ & To study each delimited context part to be analyzed in the audiovisual aid. \\
\hline \multirow{5}{*}{$\begin{array}{l}\text { Interpretation: is the comprehension or internalization } \\
\text { (correct or incorrect) of a matter, content or symbolism. It } \\
\text { supposes the penetration into the essence or meaning of a } \\
\text { text, as well as the declaration of its meaning, in } \\
\text { correspondence with the subject's previous knowledge. }\end{array}$} & To analyze the audiovisual aid content \\
\hline & To relate the parts of the audiovisual aid content \\
\hline & To find the logic of the relation between the parts of the audiovisual aid content \\
\hline & $\begin{array}{l}\text { To elaborate the conclusions about the elements, relations and reasoning that appears in the } \\
\text { content of the audiovisual aid to be interpreted. }\end{array}$ \\
\hline & To feel emotion for the context expressed in the audiovisual aid \\
\hline \multirow{3}{*}{$\begin{array}{l}\text { Awareness: is the elevation of sensitivity because of the } \\
\text { interaction of the analyzers and the exercise. }\end{array}$} & To identify with the content expressed in the audiovisual aid \\
\hline & To show satisfaction for the content expressed in the audiovisual aid \\
\hline & To feel pleasure for the content expressed in the audiovisualaid. \\
\hline \multirow{3}{*}{$\begin{array}{l}\text { Valuation: is the expression of a judgment that characterizes } \\
\text { the extent to which an object, phenomenon or process } \\
\text { corresponds to the system of knowledge, norms, and values } \\
\text { previously assimilated. }\end{array}$} & To characterize the content of the audiovisual aid to be valued \\
\hline & To establish the valuation criteria (values) of the content expressed in the audiovisual aids \\
\hline & \\
\hline
\end{tabular}

From a practical viewpoint, training on this skill is required to achieve its mastery, since an early age the learners are taught to observe and value the surrounded world, the environment and visually manifestation. However, in the current contexts, with the vertiginous development of TICs and the use of the AVA by teachers, their appreciation has been forgotten.

To understand the magnitude of this process, the analysis starts with the study of several procedures that have been implemented in Cuba and they serve as a reference for others countries on the achievement of an adequate appreciation, and at the same time, a starting point for the appreciation of the audiovisual aids, they are:

\section{SYSTEM- FORM}

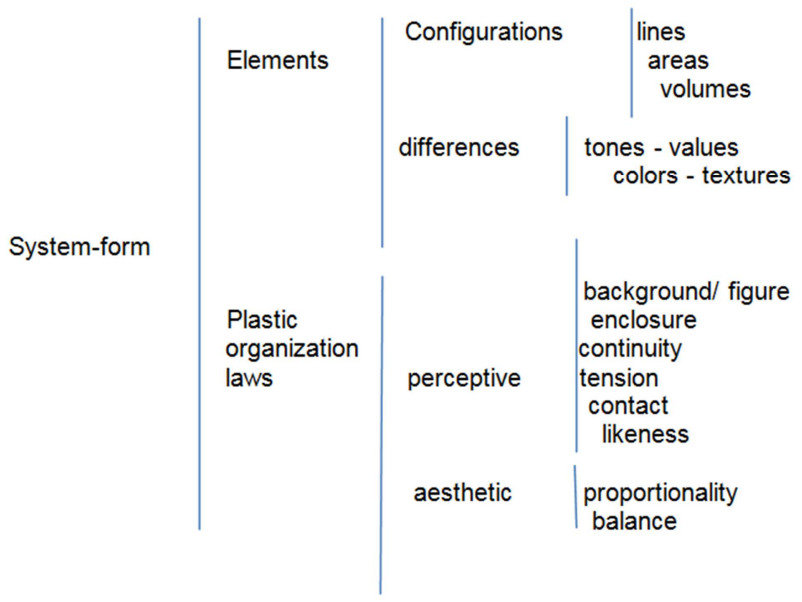

Figure 1. Fundamentalsof the system-form. [26]
The represented procedure is based on the perceptualartistic experience, where it will be compared, judged and valued from the conceptual-visual recognition, expanding its sensitivity towards forms.

This valid model, for the audiovisual production, provides to the person a set of tools that help teachers to organize the information that is generated with the use of audiovisual aids and that is assimilated by the sense organs. It also guides the activities to be undertaken by the teacher and the student; it studies the expressive elements of the visual, sound, and audiovisual language, facilitating its comprehension.

In a general way, the previous procedures provide the basic knowledge and tools for facing the vast visual and audiovisual surrounded formal world, with a great analytical and critical sense when bringing teachers and students closer to the study of visuals and audio visual manifestations. However, in our opinion, it requires its own procedure for appreciating the audiovisual aids.

The proposal starts from the foundation that the appreciation of the audiovisual aids is considered a skill, in which the basic operations as observation, analysis, interpretation, sensitivity and valuation should not be lacking. These operations are presented in the following guide:

The observation and collection of the general facts from the work, like the title, country of production, year, product directions, production (write anonymous in case that the author's name does not appear), genre (documentary, explanatory or experimental, or other), presentation format (film or video) and the socio-historical context in which is developed. 


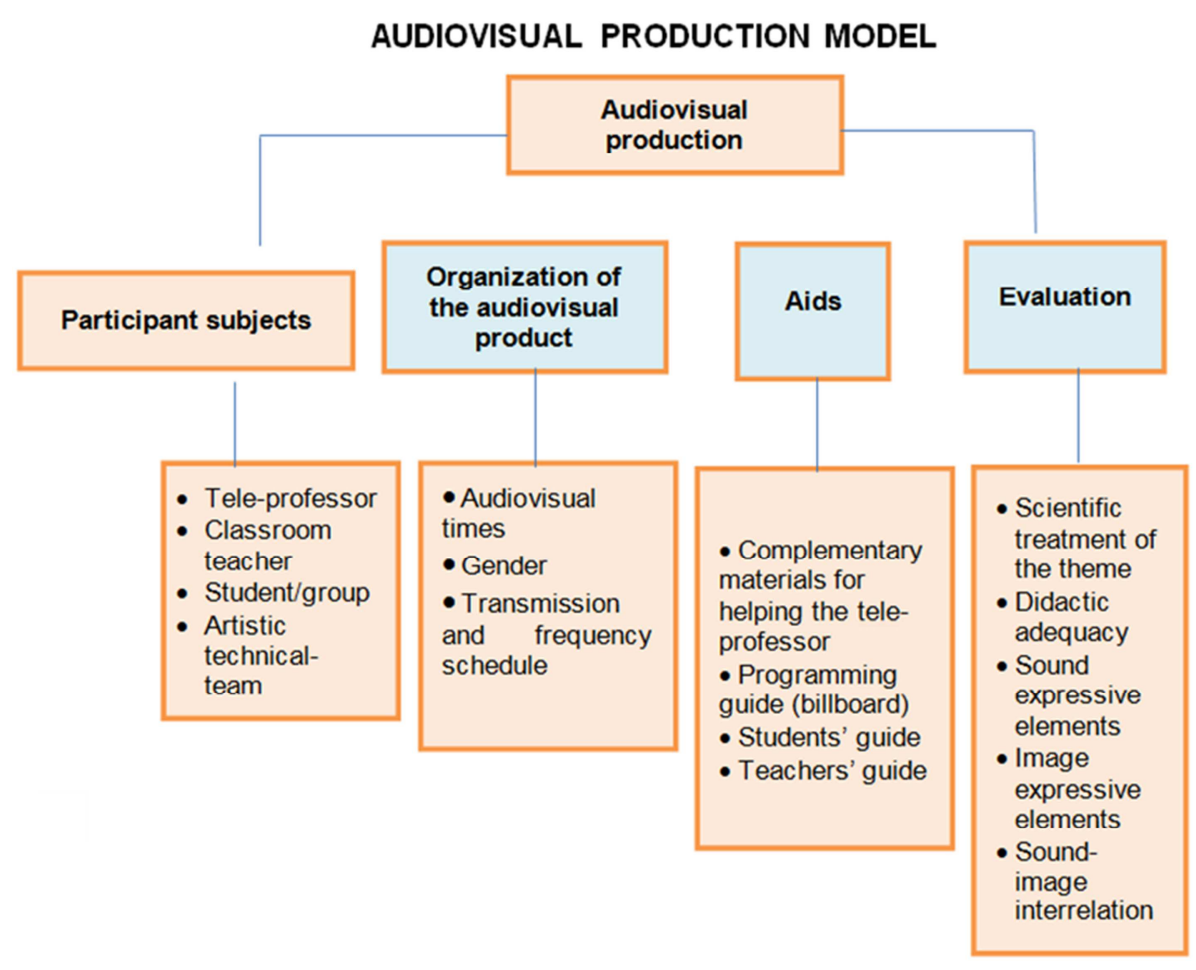

Figure 2. Audiovisual production model. [38]

Analysis and interpretation of the formal elements that appear in the audiovisual aids as: expressive elements of the audiovisual language, the role of the media; its general characteristics.

Analysis, sensibility and valuation of the conceptual elements, the experiences, the involvements, the values of the work, the caused impact, the transmitted feelings and the awaken sensibility.

In a general respect, the audiovisual language is nourished from the rest of the languages, including the visual and sound to conform the audiovisual; it also uses different expressive resources as color, lines, forms, lights, shadows, textures, and signs. It includes voices, silence, music and soundtrack, photography, scenery, costumes, makeup and hairdressing. It is added script, edition and assembly among others. All of them offer dissimilar meanings in the audiovisual work, depending on what you want to signify.

Societies are constantly subjected to the images, signs, sounds and information bombing that comes from the sight and hearing senses or simultaneously through the audiovisual aids. To meet this growing reality, it is required that from the pedagogical context should be warned, with a greater certainty, about subliminal messages that may have harmful or unsafe contents, and consequently, to make the appropriate valuations to develop an appreciative consciousness in a part of the society.

Let us think then, how necessary it becomes to be conscious about the implication of audiovisual aids appreciation in our lives and for education. If we really want to form people prepared for this kind of society that is coming, capable of appreciating for themselves objects, media, context, processes and phenomena that surround them and from which they nourish in their activity.

\section{Results and Discussion}

The consulted sources provide valuable information for research on the use of ICTs in general and AVAs in particular, however, in the documents consulted there is no evidence of the particularized treatment of the ability to appreciate and when we extrapolate it to the audiovisual world, there are gaps in this sense. The absence of research in this field has allowed the authors to promote the use and appreciation of audiovisual aids in the educational context, taking advantage on the development of the ability to appreciate, since it is not conceivable that an educator uses the audiovisual aids in his classes and cannot communicate the necessary and timely information on the subject to be discussed by means of the audiovisual aid used.

Therefore, as part of the theoretical and practical experiences, a methodological procedure is proposed that allows developing the ability to appreciate audiovisual aids through basic operations and actions, such as observation, analysis, interpretation, awareness and valuation, which fulfill a systemic function and for its achievement is required methodological treatment.

It is necessary to specify that is not the same to consume and understand an audiovisual product in a superficial way than deepen on its language knowledge to decode it and get the message and then proceed to create and produce an own product, (interpretation, judgment and valuation process that is fulfilled with the appreciation of the audiovisual aid).

In the appreciative process intervenes some factors, among them: the context, the intentionally, culture, creativity, 
ideology, the particular history moment, the experiences and involvements, as well as morphological, semantics, syntactic, stylistic and aesthetics aspects, among others.

To appreciate the language in the audiovisual aids will make us more critics and conscious from the influences of informal educative agents like the television, the radio, the cinema, a video, the press, mentioning just a few. It will also enable an effective communication with our speakers.

All what is exposed reaffirm the significant role that has the audiovisual aids to comprehend the actual processes, the subliminal and problematizing messages that comes to us daily as a result of the scientific and technical advances.

In this way, the need to promote the use and appreciation of audiovisual aids arises, for which solid arguments and evidences are offered in this area; so that -in the words of the authors- the understanding of its complexity is favored, and consequently, the processes mediated by ICT and specifically by AVAs in the educational context are optimized.

\section{Conclusions}

Because of the importance, that reaches the integration of the technologies of information and communication in the formation of a general and integral culture, at asocial scale, some foundations have been offered about the use and appreciation of the audiovisual aids during the educational teaching work.

What is important in the pedagogical practice is to comprehend that the audiovisual aid functions as a whole and that whole should be decomposed in parts and to find the meaning of each of its parts in order to access to the real meaning within the analyzed context. Therefore, the operations and actions that are proposed for its comprehension are keys.

This makes that in current times, the university teacher should be permanently updated regarding the use and appreciation of the audiovisual aids to achieve a better performance of his functions and responsibilities; he could answer with preparation to the changes and transformations that generates the technologies of information and communication.

If we have to train the new professionals to work in an increasingly audiovisual world, we must recognize the dimension of the problem in terms of complexity in the development of the audiovisual aids appreciation skill in current educative contexts.

\section{References}

[1] López, A. (2007). Methodology for the assimilation of information and communication technologies in the teaching learning process of technical and agricultural sciences. Agricultural and Technical Science Magazine, 2 (16), pp. 6368 .

[2] Cabrera, R., J., F. (2008). Virtual Resource Center Model to contribute to the integration of ICT in the Teaching Learning Process at the "Jose Antonio Echeverria" Higher Polytechnic
Institute. Thesis presented as an option to the Scientific Degree of Doctor in Education Sciences. Havana City. "Jose Antonio Echeverria" Higher Polytechnic Institute. Reference Center for Advanced Education. Havana City.

[3] Alcántara, T., M. D. (2009). Importance of TICs for education. Digital Magazine: Innovation and educative experiences. ISNN19886047. No15- February 2019.

[4] Garay, C., L. M. (2009). Information and communication technologies. Interdisciplinary horizons and research topics. /Coord. Luz María Garay Cruz- Mexico: UPN, 2009. 216p. ISBN: 978-607-413-036-2.

[5] Area, M., M. (2010). The process of integration and pedagogic use of ICTs in the educative centers. A case study. Education Magazine, 352. May-August 2010.

[6] Álvarez, A., A. (2014). Pedagogical-technological strategy for the integration of information and communication technologies in the teaching learning process from the production of digital educational materials at the "Jose Antonio Echeverria" Higher Polytechnic Institute. Thesis presented as an option to the Scientific Degree of Doctor in Education Sciences. Havana City. "Jose Antonio Echeverria" Higher Polytechnic Institute. Reference Center for Advanced Education.

[7] Osorio, G., M. (2016). Book 3. The information and communication technologies (ICTs): Advances, and challenges in educational transformation. (2016). /Coord. Maricela Osorio Guzmán. II Congress on Education Transformation. Alternatives for new educational practices. Edition: Amapsi, Editorial, street Hygiene Institute No. 56. Col. Popotla, Delegation Miguel Hidalgo. C. P. 11400. ISBN: 978-607-7506-14-0.

[8] Adame, T., A. (2009) Audiovisual Aids in the classroom. ISNN 1988- 6047. Dep. Leg. 2922/2007, No. 19 June- 2009. Granada.

[9] (Barros, B., C. Barros, Barros, M., R. (2015). The audiovisual aids and its influence on education from alternatives of analysis. University and Society Magazine [online serials], Vol. 7 No (3). pp. 26-31. Recovered from http://rus.ucf.edu.cu/.

[10] (Ortiz, S., D. (2017). Digital infography system for the subject: Civil Law, General Part. Thesis in option to the Master Degree in Higher Education. Havana.

[11] (Area, M. (2005). The information and communication technologies in the school. A review of the research lines. "Relieve", Electronic Journal of Educational Research and Evaluation, 11 (1). (pp. 3-25) Recovered on April $10^{\text {th }} 2009$ from

http.//www.uv.es/RELIEVE/v11n1/RELIEVEv11n1_1.htm.

[12] (Area, M. (2006). Twenty years of institutional policies to incorporate the information and communication technologies to the academic system. In J. Ma . Sancho, (Coord.), Technologies to transform education. Madrid: Akal.

[13] Zilbersteinand Collazo ([n.d.]) In Pedagogical Preparation for the New Cuban University Professors. (2009)/ Comp. Elsa M. Herrero Tunis and Ramón Collazo Delgado: Havana: Editorial "Félix Varela". ISBN: 978-959-07-1031-5.

[14] González, C., V. (1986). Theory and practice of the teaching aids. Havana City: Editorial "Pueblo y Educación". 
[15] Communication and Education Office of the Autonomous University of Barcelona. (2015). Perspectives 2015: The use of the audiovisual in the classrooms. The situation in Spain. Editorial Planet. S. A. U., Spain.

[16] Bartolomé, A., (1987). Audiovisual Language - Audiovisual World. Obtained from: http://www.lmi.ub.es/personal/bartolome/articuloshtml/bartolo me_lav.

[17] Cabero, A., J. (2002). Analysis, selection and evaluation of the didactics audiovisual aids. Obtained from: http://tecnologiaedu.us.es/revistaslibros/qurricul.html.

[18] (Bustos, F., P. López, S., N. Meriño, V., C. Molina, L., C and San Martin, F., V. (2012). The use of the audiovisual materials and its influence on the English language learning. Seminar to qualify for the title of Secondary English Education Teacher.

[19] Repetto, J., E. Calvo, F., J. R. (2003). The use of audiovisual resources in higher education. The Guiniguada, No. 12. University. Editor.

[20] Bartolomé, A. Grané, M. Mercader, A. Pujola, J.- T. Rubinstein, V. Willem, C. (2007). The audiovisual Web. Technology and Educative Communication Magazine Year 21, No. 45. /July-December 2007.

[21] Collazo, R., D. (2009) quote a group of Cuban authors (1984) The media in the teaching learning process. In: Pedagogical Preparation for the New Cuban University Professors. / Comp. Elsa M. Herrero Tunis and Ramón Collazo Delgado. Havana: Editorial“Félix Varela". ISBN: 978-959-07-1031-5.

[22] Porto, A. (2016). Training in virtual learning environments and social networks: Editorial Gráfica Jivas. UMSA. La Paz, Bolivia.

[23] Ballesteros, R., C. (2016). The audiovisual aids: Didactic functions and methodological principles for its integration in the teaching learning process. IJERI: International Journal of Educational Research and Innovation, $\mathrm{N}^{\circ} 6,58-70$.

[24] Parra, R., N. A. Rocha, R., A. M. (2016). Pedagogical functionalization of the short film resource, a didactic proposal for high school students. Chile: Bío-Bío University.

[25] Castañeda, Yanes., M. (1992) Communication and educative technology aids. Mexico: TRILLAS ( $2^{\mathrm{a}}$ ed. $2^{\mathrm{a}}$. print.) ISBN: 968-24-0988-8.

[26] Morriña R., O. (2010). Fundamentals of form. The Havana. Editorial "Félix Varela". (3 ${ }^{\text {rd }}$ print.) ISBN 959-258-959-3.

[27] Ruiz, L., Castro, M., Fiallo, M., Hernández, M. A., Paz, N \&
Junco, R. (1991). Methodology of Plastic Education in childhood. Havana: Editorial "Pueblo y Educación".

[28] Cabrera S., R. (2013). Visual Arts Appreciation. (4 ${ }^{\text {th }}$ print.) Havana city: Editorial "Pueblo y Educación". ISBN 978-95913-2669-0.

[29] Junco, R. (1991). Notes on the visual arts in Cuba. Havana: Editorial "Pueblo y Educación"

[30] Oscar, M. ([n.d].) Introductory course to the History of the Plastic Arts. In "University for all" Tabloid. Havana: Editorial: "Pueblo y Educación".

[31] Toledo, M., R., J. (2008). The development of the artistic appreciation on the plastic arts in high school students. Thesis presented as an option to the Scientific Degree of Doctor in Pedagogical Sciences. Holguin, Cuba.

[32] Roper, D., A. M. Laffita, A., M. (2009) System of activities to contribute to the development of the ability to appreciate artistically in the first year of the pedagogical careers. Available

http://www.revistaedusoc.rimed.cu/index.php/eivart\%C3\%ADculos/el-desarrollo-de-la-habilidad-apreciar.

[33] Gascón, M., J. C. (2010). The work of art facing the dilemma of its appreciation. Digital support. Available in: http://www.cubaliteraria.cu/articulo.php?idarticulo=11783\&id seccion $=33$. Consulted on $\left(\right.$ October $\left.2^{\text {nd }} 2013\right)$.

[34] Seijas, B., C. R. (2017-2019). Methodological Workshop with Aspirants. University of Pedagogical Sciences "Enrique José Varona" (October $\left.21^{\text {st }} 2020\right)$.

[35] Álvarez, de Zayas., R. M. (1997). Methodology of History teaching. Havana City: Editorial "Pueblo y Educación".

[36] Alfonso, C., A. (2017). The audiovisual appreciation, an educational need for Higher Education Centers. In international workshop "The teaching of humanistic disciplines" 2017.

[37] Piedra, N., I. N. Álvarez, G., Y. Padrón, Martínez., M. Ortega, M., W. R. Urra, D., I. Alfonso, Castro., A. Aguiar, Hernández., E. García, Vázquez., B., M. Hernández, H., Y. Martínez, Capote., F. A. and Pujol, Pérez., E.(2016). Artistic Education Discipline Program. Ministry of Higher Education. Havana City, Cuba.

[38] Barreto, Gelles., I. del Toro, Rodríguez., M. Riquenes, Tarragó., A. (2009). Educational technology: Two models for teacher action. Sello Editor Educación Cubana. Ministry of Education. ISBN 978-059-18-0430-3.

\section{Biography}

Abel Alfonso Castro: Assistant Professor, during 13 years he has served as head of the Arts Education Department, head of Social Science Department, Vice-Dean of Development and Research, of the Faculty of Social and Humanistic. His scientific results have been presented in dissimilar national and international events, and they have been published in high impact magazines and in texts of his major. He has been a coordinator of lines of research related to the development of Plastic Arts and its territorial identity. Nowadays, he is a member of the National Commission of Artistic Education Career and he has majored on the appreciative process.

Yuri Belén Ramírez: Full Professor, 13 years of experience in the Higher Education, he has served as head of the Marxism Leninism and History Department, and lately as Dean of the School of Social and Humanistic Sciences during five (5) years. His scientific activity is centered on the History of Education and the cultural processes. He has led different lines of research in projectsof I+D+I Master's degree, undergraduate and course theses. 
Carmen Rosa Seijas Bagué: Full Professor, 34 years of experience in the educational sector; she has served as National Methodology of Arts Education and nowadays she works as an adviser of the Vice-Rector. In her scientific dimension, she has stood out for leading different lines of research in projects of $\mathrm{I}+\mathrm{D}+\mathrm{I}$ and theses. She is at the head of the Plastic Education discipline in the Third Improvement of the Cuban Educational System, in the elaboration of curriculums and methodological guidelines; she attends from the institution, the editorial plan for updating the bibliography.

Ana María Reyes Suárez: Assistant Professor, 12 years of experience in the Higher Education, during 6 years she was at the head of the Foreign Language Department. Her scientific activity is centered on the Perfection of the Teaching Learning Process of English Language. She has stood out for advising different lines of research in teachers in training during three years in Kwanza Norte, Angola.

Edward Peter. Kardas is distinguished professor of psychology and director of the Honors College at Southern Arkansas University. He received his $\mathrm{PhD}$ in Comparative-Developmental psychology from Louisiana State University and previously taught at Louisiana State University at Eunice and the University of Wisconsin-Milwaukee. He is the author or co-author of several textbooks, most recently one in the history of psychology. He is co-editor (with Tracy Henley and Matt Rossano) of The handbook of cognitive archeology. 